\title{
FAKTOR-FAKTOR YANG MEMPENGARUHI PENGELUARAN RUMAH TANGGA PETANI KARET DI KABUPATEN BANYUASIN SUMATERA SELATAN
}

\author{
Oleh : \\ Siti Komariah Hildayanti \\ Program Magister Manajemen UIGM Palembang \\ Email : Hildayanti@uigm.ac.id \\ Tirta Jaya Jenahar \\ Program Magister Manajemen UIGM Palembang \\ Email : tirtajaya@uigm.ac.id \\ Harris Oemar \\ Universitas Batam
}

\begin{abstract}
ABSTRAK
Penelitian ini bertujuan untuk menganalisis faktor-faktor yang mempengaruhi pengeluaran rumah tangga petani. Pengumpulan data primer secara acak dilakukan pada bulan Maret sampai Mei 2016 dengan mewawancara sebanyak 60 petani responden pada 6 desa sebagai perwakilan dari Kabupaten Banyuasin di Sumatera Selatan. Analisis data menggunakan analisis regresi.

Hasil penelitian menunjukan bahwa pengeluaran rumah tangga petani berpengaruh positif, terhadap pendapatan rumah tangga petani, jumlah keluarga dan peremajaan karet dan pengaruh negatif terhadap tabungan rumah tangga, pendidikan formal dan pengeluaran konsumsi.
\end{abstract}

Kata kunci : Analisis regresi, pengaruh., pengeluaran rumah tangga.

\section{PENDAHULUAN}

Perkebunan karet alam di Sumatera Selatan sangat strategis karena provinsi ini pada tahun 2014 merupakan daerah penghasil utama karet alam di Indonesia dengan total produksi 576.676 ton atau $35,66 \%$ dari produksi karet Indonesia. Kontribusi karet alam terhadap Produk Domestik Regional Bruto (PDRB) Sumatera Selatan sebesar Rp 2.861 juta atau $9,07 \%$ dari total PDRB dan dari produksi karet tersebut sebanyak $62 \%$ diekspor yang merupakan masukan devisa negara sebesar US $\$ 280,4$ juta $(34 \%)$ dari ekspor Sumatera Selatan juga sebagai sumber kebutuhan hidup sekitar 429.846 KK atau sekitar 2 juta penduduk Sumatera Selatan (Dinas Perkebunan Provinsi Sumatera Selatan, 2014).
Pengembangan pembangunan karet rakyat di Sumatera Selatan dari berbagai proyek pemerintah berbantuan (Proyek Perusahaan Inti Rakyat dan Unit Pelaksana Proyek, Parsial) selama 25 tahun (1997/1998 s/d 2002) tercatat mencapai seluas 224.721 ha atau sekitar 8.988 ha per tahun. Sejak tahun 1992-2011. Pemerintah Daerah Sumatera Selatan telah memperhitungkan biaya untuk meremajakan tanaman karet seluas 100.000 ha yaitu sekitar Rp 776,25 milyar yang diprogramkan selama kurun waktu 5 tahun (2012-2016) (Dinas Perkebunan Provinsi Sumatera Selatan, 2012). Apabila keseluruhan dana tersebut dibebankan kepada anggaran pemerintah daerah tentu akan memberatkan. Oleh karena itu usahatani petani perlu didorong dan difasilitasi untuk me-remajakan tanaman 
karetnya secara mandiri. Fasilitas yang dapat diberikan pemerintah daerah antara lain bantuan parsial (bahan tanaman karet), pembinaan teknis dan penyuluhan (Supriadi et al., 2010).

Hasil penelitian Supriadi et al. (2010), di Kabupaten Musi Banyuasin Sumatera Selatan mengungkapkan bahwa sebagian besar pengeluaran keluarga tani karet (82-83\%) digunakan untuk kebutuhan konsumsi pokok. Pengeluaran untuk pemeliharaan kebun sangat kecil, yaitu sekitar 3\% di Kecamatan Sungai Keruh dan kurang dari $1 \%$ di Kecamatan Babat Toman. Alasan pokok rendahnya pengeluaran untuk investasi kebun ini adalah minimnya pendapatan petani di samping juga faktor kurang tingginya motivasi berinvestasi.

Hasil penelitian Rifai (2000) mengungkapkan bahwa pendapatan yang diperoleh petani peserta Proyek Pengembangan Budidaya Perkebunan Rakyat (PBPR) adalah sebesar Rp 6.934.958,33 per ha per tahun. Hasil penelitian Gunawan dan Supriadi (1988), yang dilakukan di Proyek Pengembangan Karet Rakyat-Unit Prabumulih, Sumatera Selatan menunjukkan bahwa peani mengutamakan penggunaan pendapatannya untuk konsumsi pangan 61 persen.

Dari kenyataan dan harapan tersebut dapat disimpulkan bahwa yang menjadi masalah pokok adalah faktor-faktor apa saja yang mempengaruhi pengeluaran rumah tangga petani karet rakyat? Penelitian ini secara umum bertujuan untuk menganalisis faktor-faktor yang mempengaruhi pengeluaran rumah tangga petani karet rakyat di Sumatera Selatan. Hasil penelitian ini diharapkan berguna untuk mengembangkan model pendugaan pengaruh non ekonomi di samping ekonomi terhadap pengeluaran rumah tangga petani untuk memenuhi kebutuhan hidupnya.

\section{TINJAUAN PUSTAKA DAN MODEL PENDEKATAN}

Hubungan antara pendapatan dan konsumsi telah banyak mendapatkan perhatian. Nicholson (1995) menyatakan bahwa teori dari seorang ekonom Prusia yaitu Ernst Engel (1821-1896) masih tetap diyakini kebenarannya hingga saat ini. Suatu kesimpulan yang penting dari Engel adalah "proporsi penghasilan rumah tangga yang dibelanjakan untuk makanan menurun ketika penghasilan meningkat".

Samuelson dan Nordhaus (1986) menyatakan pola perilaku konsumen yang disebut sebagai "Kaidah Engel" adalah jika pendapatan meningkat, maka persentase pengeluaran untuk konsumsi makanan menurun, persentase pengeluaran untuk konsumsi pakaian dan perumahan relatif tetap, persentase pengeluaran untuk kesehatan, pendidikan, rekreasi, barang mewah dan tabungan makin besar. Keluarga yang berpendapatan tinggi mengkonsumsi makanan yang berkualitas dan banyak ragamnya.

Berdasarkan tujuan penelitian yang akan dicapai maka diajukan hipotesis berkenaan dengan faktor yang mempengaruhi pengeluaran rumah tangga petani sebagai berikut “ Diduga pengeluaran total rumah tangga petani dipengaruhi secara positif oleh pendapatan total, jumlah anggota keluarga, usia petani, konsumsi, pendidikan formal dan model peremajaan dipengaruhi secara negatif oleh tabungan rumah tangga.

Batasan operasional dari beberapa istilah sebagai berikut :

1. Tanaman karet tua atau rusak adalah tanaman karet yang berumur lebih dari umur eko-nomis (>25 tahun), sedangkan tanaman karet rusak sebagai akibat kurang pemeliharaan dan penyadapan yang berat.

2. Rumah tangga keluarga dalam arti ekonomi adalah sekelompok orang yang hidup dalam satu rumah 
mengelola ekonomi keluarga, pembagian kerja, pendapatan, konsumsi, jenis produksi dan jasa yang dihasilkan.

3. Petani karet dalam penelitian ini adalah petani pekebun rakyat yang memiliki kebun karet dan menggarapnya sendiri sebagai mata pencarian pokok.

4. Model peremajaan tanaman karet adalah penanaman tanaman karet yang dilakukan di atas lahan bekas tanaman lama diukur dalam hektar.

\section{METODE PENELITIAN}

Penelitian dikembangkan dengan pendekatan ilmiah melalui proses deduktif dan induktif. Rangkaian dari pendekatan ilmiah demikian adalah mengidentifikasikan permasalahan, menentukan tujuan penelitian, membangun hipotesis, merancang prosedur penelitian, melakukan analisis terhadap data dan informasi, serta menginterpretasikan data dan menarik kesimpulan.

Tempat penelitian adalah desa-desa terpilih atau rumah tangga petani di Kabupaten Banyuasin Provinsi Sumatera Selatan. Wilayah penelitian Kabupaten Musi Banyuasin Provinsi Sumatera Selatan dipilih dengan pertimbangan bahwa kabupaten ini dapat mewakili kabupaten yang luas perkebunan karet rakyatnya dan Provinsi Sumatera Selatan memiliki luas areal perkebunan karet rakyat terluas di Indonesia yaitu 27,5\% dari total luas areal perkebunan karet rakyat di Indonesia. Di samping itu Sumatera Selatan merupakan penghasil utama karet di Indonesia yaitu 35,6\% dari total produksi. Sedangkan waktu penelitian ini akan dilaksanakan mulai bulan Maret 2016 sampai dengan Mei 2016.

Penarikan sampel yang dipakai adalah sampel bertahap (multi stage sampling) dengan quota terhadap kecamatan dan desa. Dari setiap kecamatan dipilih secara sengaja acak 6 desa sebagai perwakilan dengan kriteria areal karet terluas Dari setiap desa kemudian diambil sampel secara acak sebanyak 10 sampel petani dari kerangka sampel desa terpilih,sehingga julah sampel sebanyak 60 petani.

Metode pengumpulan data melalui wawancara langsung dengan petani sampel dan meng-adakan studi pendalaman terhadap hasil pengumpulan data. Wawancara dilakukan meng-gunakan daftar pertanyaan yang berisikan pertanyaan-pertanyaan terbuka dan tertutup yang berkaitan dengan variabel yang mempengaruhi pengeluaran rumah tangga petani karet rakyat

Pengolahan data dengan menggunakan perangkat software komputer SAS. Data yang di-kumpulkan dari survei diolah mengikuti prosedur untuk pengkajian hipotesis yang telah dirumuskan. Tabulasi data diolah dengan menggunakan program Excel. Pengujian hipotesis di-lakukan dengan Analisis regresi terhadap model pendugaan ekonomitrika untuk menduga faktor-faktor yang mempengaruhi pengeluaran rumah tangga petani.

\section{HASIL PENELITIAN DAN PEMBAHASAN}

\section{Faktor Yang Mempengaruhi Pengeluaran Rumah Tangga Petani}

Pengeluaran rumah tangga petani diduga dipengaruhi secara positif oleh pendapatan rumah tangga petani $\left(\mathrm{Y}_{\mathrm{t}}\right)$, jumlah keluarga $\left(\mathrm{J}_{\mathrm{k}}\right)$, peremajaan karet $(\mathrm{D})$ dan dipengaruhi secara negatif oleh usia petani $\left(\mathrm{U}_{\mathrm{s}}\right)$, pengeluaran kebutuhan pokok (Cc), pendidikan formal $\left(\mathrm{P}_{\mathrm{d}}\right)$ dan tabungan rumah tangga $\left(T_{r}\right)$. Analisis regresi untuk melihat determinan menghasilkan fungsi penduga sebagai berikut :

$$
\begin{aligned}
& \mathrm{C}_{\mathrm{t}}=1197+1,01 \mathrm{Y}_{\mathrm{t}}+4,05 \mathrm{~J}_{\mathrm{k}}-0,06 \mathrm{U}_{\mathrm{s}}- \\
& 0,01 \mathrm{C}_{\mathrm{c}}-1,0 \mathrm{~T}_{\mathrm{r}}-0,66 \mathrm{P}_{\mathrm{d}}+1,49 \mathrm{D}
\end{aligned}
$$

Dari fungsi penduga tersebut diperoleh koefisien determinasi $\left(\mathrm{R}^{2}\right)$ 
sebesar 0,99 dengan nilai $\mathrm{F}_{\text {hitung }}$ lebih besar dari $F_{\text {tabel }}$ sehingga variasi dari variabel eksogen dapat menjelaskan variasi variabel endogen pada taraf kepercayaan $95 \%$.

Parameter penduga tabungan rumah tangga $\left(\mathrm{T}_{\mathrm{r}}\right)$, usia petani $\left(\mathrm{U}_{\mathrm{s}}\right)$, konsumsi kebutuhan pokok $\left(\mathrm{C}_{\mathrm{c}}\right)$ dan pendidikan formal $\left(\mathrm{P}_{\mathrm{d}}\right)$ bertanda negatif sedangkan parameter penduga pen-dapatan rumah tangga petani $\left(\mathrm{Y}_{\mathrm{t}}\right)$, jumlah keluarga $\left(\mathrm{J}_{\mathrm{k}}\right)$, dan peremajaan karet (D) bertanda positif. Tanda parameter dari variabel tersebut belum sesuai dengan tanda yang diharapkan ter-utama usia petani $\left(U_{s}\right)$, konsumsi kebutuhan pokok $\left(\mathrm{C}_{\mathrm{c}}\right)$ dan pendidikan formal $\left(\mathrm{P}_{\mathrm{d}}\right)$. Analisis kedua dilakukan untuk melihat secara parsial pengaruh dari masing-masing variabel eksogen menghasilkan angka-angka seperti Tabel 1.

Tabel 1.

Hasil Analisis Determinan Pengeluaran Rumah Tangga Petani.

\begin{tabular}{|c|c|c|c|c|c|}
\hline No & Variabel & $\begin{array}{l}\text { Koefisien } \\
\text { Regresi }\end{array}$ & $\begin{array}{l}\text { Nilai } \\
\text { Parameter }\end{array}$ & $\mathrm{t}^{\prime} \mathrm{t}_{\text {hitung }}$ & Signifikan \\
\hline 1 & Intersep & $b_{0}$ & 1197 & 78,6 & 0,0001 \\
\hline 2 & Pendapatan petani $\left(\mathrm{Y}_{\mathrm{t}}\right)$ & $b_{1}$ & $1,01 * *$ & 381,6 & 0,0001 \\
\hline 3 & Jumlah keluarga $\left(\mathrm{J}_{\mathrm{k}}\right)$ & $b_{2}$ & $4,05 * *$ & 1,022 & 0,3072 \\
\hline 4 & Usia petani $\left(\mathrm{U}_{\mathrm{s}}\right)$ & $b_{3}$ & $-0,06$ & 0,229 & 0,8187 \\
\hline 5 & Konsumsi kebutuhan pokok $\left(\mathrm{C}_{\mathrm{c}}\right)$ & $b_{4}$ & $-0,006 *$ & $-1,333$ & 0,1833 \\
\hline 6 & Tabungan RT $\left(\mathrm{T}_{\mathrm{r}}\right)$ & $b_{5}$ & $-1,004 * *$ & $-343,1$ & 0,0001 \\
\hline 7 & Pendidikan formal $\left(\mathrm{P}_{\mathrm{d}}\right)$ & $b_{6}$ & $-0,66 *$ & $-1,153$ & 0,2497 \\
\hline 8 & Peremajaan karet (D) & $b_{7}$ & $1,496 * *$ & 0,308 & 0,7584 \\
\hline
\end{tabular}

Keterangan : * Pengaruh nyata pada tingkat kepercayaan 95\%

** Pengaruh nyata pada tingkat kepercayaan $99 \%$ 
Pada Tabel 1 terlihat bahwa secara keseluruhan variabel eksogen berpengaruh nyata dan sangat nyata terhadap pengeluaran rumah tangga $\left(\mathrm{C}_{\mathrm{t}}\right)$ kecuali usia petani $\left(\mathrm{U}_{\mathrm{s}}\right)$, konsumsi ke-butuhan pokok $\left(\mathrm{C}_{\mathrm{t}}\right)$ dam pendidikan formal $\left(\mathrm{P}_{\mathrm{d}}\right)$. Secara khsusus dapat dijelaskan bahwa :

1. Pendapatan rumah tangga petani $\left(Y_{t}\right)$ berpengaruh secara positif dan sangat nyata terhadap pengeluaran rumah tangga petani $\left(\mathrm{C}_{\mathrm{t}}\right)$, dengan nilai parameter 1,01. Ini berarti pendapatan total $\left(\mathrm{Y}_{\mathrm{t}}\right)$ lebih banyak menentukan naik atau turunnya searah dengan konsumsi rumah tangga petani $\left(\mathrm{C}_{\mathrm{t}}\right)$ sebesar 1,01. Semakin besar pendapatan maka akan semakin besar hasrat untuk berkonsumsi.

2. Tabungan rumah tangga $\left(\mathrm{T}_{\mathrm{r}}\right)$ berpengaruh negatif dan sangat nyata terhadap pengeluaran rumah tangga petani $\left(\mathrm{C}_{\mathrm{t}}\right)$, dengan nilai parameter penduga $-1,04$. Ini berarti tabungan rumah tangga $\left(\mathrm{T}_{\mathrm{r}}\right)$ lebih banyak menentukan naik atau turunnya secara berlawanan arah konsumsi rumah tangga petani $\left(\mathrm{C}_{\mathrm{t}}\right)$ sebesar - 1,04. Semakin besar tabungan rumah tangga akan mengakibatkan mengurangi pengeluaran rumah tangga petani baik untuk pengeluaran konsumsi atau pengeluaran lainnya.

3. Usia petani $\left(U_{s}\right)$ tidak berpengaruh terhadap pengeluaran rumah tangga petani $\left(C_{t}\right)$ dengan nilai parameter penduga $-0,06$. Ini berarti usia petani tidak berdampak pada pengeluaran rumah tangga petani. Hal ini dapat terlihat dari data empiris bahwa pengeluaran rumah tangga petani tidak proposional dengan meningkatnya usia petani tetapi lebih diindikasi oleh status sosial masyarakat.

4. Konsusmsi kebutuhan pokok $\left(\mathrm{C}_{\mathrm{c}}\right)$ berpengaruh secara negatif dan nyata terhadap penge-luaran rumah tangga petani $\left(\mathrm{C}_{\mathrm{t}}\right)$ dengan nilai parameter 0,006. Ini berarti konsumsi ke-butuhan pokok berdampak pada pengeluaran rumah tangga petani. Hal ini dapat terlihat dari data empiris bahwa konsumsi kebutuhan pokok menentukan naik dan turunnya secara berlawanan arah terhadap pengeluaran rumah tangga petani.

5. Jumlah keluarga $\left(\mathrm{J}_{\mathrm{k}}\right)$ berpengaruh secara positif dan sangat nyata terhadap pengeluaran rumah tangga petani $\left(\mathrm{C}_{\mathrm{t}}\right)$ dengan nilai parameter penduga 4,05. Ini berarti jumlah keluarga $\left(\mathrm{J}_{\mathrm{k}}\right)$ lebih banyak menentukan naik atau turunnya searah dengan pengeluaran rumah tangga petani sebesar 4,05. Hal ini dapat dipahami karena semakin banyak anggota keluarga se-makin banyak pengeluaran rumah tangga petani terutama untuk keperluan sehari-hari masing-masing individu dalam keluarga.

6. Pendidikan formal $\left(\mathrm{P}_{\mathrm{d}}\right)$ berpengaruh secara negatif dan nyata terhadap pengeluaran rumah tangga petani $\left(\mathrm{C}_{\mathrm{t}}\right)$ dengan nilai parameter penduga $-0,66$. Ini berarti pendidikan formal berdampak pada pengeluaran rumah tangga petani. Bukti ini menunjukkan tingkat pen-didikan yang ditempuh petani akan mempengaruhi petani untuk meningkatkan atau me-nurunkan pengeluaran rumah tangganya secara berlawanan arah.

7. Peremajaan karet (D) berpengaruh secara positif dan sangat nyata terhadap pengeluaran rumah tangga petani $\left(C_{t}\right)$ dengan nilai parameter penduga 1,496. Ini berarti peremajaan karet lebih banyak menentukan naik atau turunnya searah dengan pengeluaran rumah tang-ga petani sebesar 1,496. Hal ini dapat dipahami, karena untuk melakukan peremajaan diperlukan biaya untuk bahan tanaman klon unggulan. 


\section{KESIMPULAN DAN SARAN}

Dari hasil analisis dan pembahasan mengenai faktor-faktor yang mempengaruhi pengeluaran rumah tangga petani karet rakyat maka dapat di tarik beberapa kesimpulan sebagai berikut beberapa faktor-faktor yang mempengaruhi pengeluaran rumah tangga petani dipengaruhi secara signifikan dan positif oleh pendapatan rumah tangga petani, jumlah keluarga dan peremajaan karet dan pengaruh secara negatif oleh tabungan rumah tangga, pendidikan formal dan pengeluaran konsumsi kebutuhan pokok dan usia petani.

\section{DAFTAR PUSTAKA}

Dinas Perkebunan Provinsi Sumatera Selatan, 2014. Statistik Perkebunan Dinas Perkebunan Provinsi Sumatera Selatan Tahun 2014, Palembang.

Koutsoyiannis. A, 1987. Theory of Econometrics. An Introductory Exposition of Econometric Methods. Mac Millan Press Ltd. USA

Nicholson. W, 1995. Microekonomic Intermediate dan Aplikasi (terjemahan oleh Agus Maulana) Bina Rupa. Aksara. Jakarta.

Rifai. N, 2000. Determinan Potensi Peningkatan Produksi Bokar Petani Peserta TCSDP Di Kabupaten Muara Enim Provinsi Sumatera Selatan. Tesis S2 UNSRI (tidak diterbitkan)
Samuelson. P.A, and Williams. D. Nordhous, 1986. Economics. Mc. Graw Hill International Editions: Singapore.

Supriadi. M., C. Nancy dan G. Wibawa, 1999. Percepatan Peremajaan Karet Rakyat Melalui Penerapan Teknologi Dan Kegiatan Pemberdayaan Masyarakat Perkebunan. Lokakarya Ekspose Teknologi Perkebunan. Palembang : 45-69.

Supriadi, M., C. Nancy, M. Jahidin. R, G. Wibawa, K. Amypalupy, 2010. Laporan Akhir Studi Karakteristik Sosial Ekonomi Peremajaan Karet Rakyat Partisipatif Di Kecamatan Sungai Keruh Dan Babat Toman Kabupaten Musi Banyuasin Sumatera Selatan, Kerja-sama Pemerintah Daerah Musi Banyuasin Dan Balai Penelitian Karet Sembawa.

Supriadi. M. dan C. Nancy, 2010. Partisipatory Rubber Replanting Model. Its Progress of Implementation In Indonesia Rubber Smallholding Sector. Sembawa Research Station. 